\title{
Sifat Kayu Lapis yang Dibuat dari Lima Jenis Kayu Asal Riau
}

\section{(Properties of Plywood Produced from Five Wood Species in Riau)}

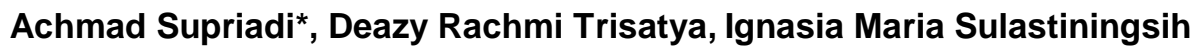

(Diterima Maret 2020/Disetujui September 2020)

\begin{abstract}
ABSTRAK
Penelitian ini bertujuan untuk mempelajari sifat-sifat fisis dan mekanis kayu lapis yang dibuat dari lima jenis kayu yang berasal dari Provinsi Riau, yaitu kayu punak (Tetramerista glabra Miq.), meranti bunga (Shorea teysmanniana Dyer ex Brandis), mempisang (Alphonsea spp.), suntai (Palaquium burckii H.J.L.), dan pasak linggo (Aglaia argentea Blume). Perekat yang digunakan adalah urea formaldehida (UF) cair. Data hasil penelitian dianalisis menggunakan Rancangan Acak Lengkap (RAL). Hasil penelitian menunjukkan bahwa kadar air kayu lapis yang dihasikan berkisar

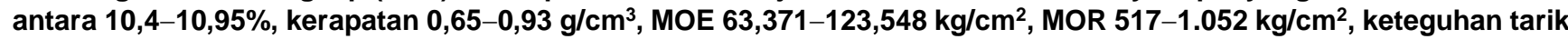
$461,6-1,095 \mathrm{~kg} / \mathrm{cm}^{2}$, dan keteguhan rekat $18,97-31,79 \mathrm{~kg} / \mathrm{cm}^{2}$. Kadar air dan keteguhan rekat kayu lapis yang dihasilkan semuanya memenuhi Standar Nasional Indonesia untuk kayu lapis penggunaan umum. Kayu lapis pasak linggo memiliki kualitas terbaik. Secara statistik, sifat fisis dan mekanis kayu lapis dipengaruhi secara nyata oleh jenis kayu, kecuali kadar air.
\end{abstract}

Kata kunci: jenis kayu asal Riau, kayu lapis, sifat fisis, sifat mekanis

\section{ABSTRACT}

The objective of this study was to determine the physical and mechanical properties of plywood made of punak (Tetramerista glabra Miq.), meranti bunga (Shorea teysmanniana Dyer ex Brandis), mempisang (Alphonsea spp.), suntai (Palaqium burckii H.J.L.), and pasak linggo (Aglaia argentea Blume). Liquid urea formaldehyde (UF) was used as an adhesive. Data analysis was carried out using a completely randomized design. Results showed that the moisture content and density of plywood produced in this study were around $10.4-10.95 \%$ and 0.65 to $0.93 \mathrm{~g} / \mathrm{cm}^{3}$, respectively. The modulus of elasticity (MOE) and modulus of rupture (MOR) of plywood produced were between $63.371-123.548 \mathrm{~kg} / \mathrm{cm}^{2}$ and $517-1.052 \mathrm{~kg} / \mathrm{cm}^{2}$, respectively. It was also found that the tensile strength and bonding strength of the plywood produced were $461.6-1.095 \mathrm{~kg} / \mathrm{cm}^{2}$ and $18.97-31.79 \mathrm{~kg} / \mathrm{cm}^{2}$, respectively. It was recorded that moisture content and the bonding strength of the plywood produced met the Indonesian National Standard of Plywood. Among others, plywood produced from pasak linggo showed a superior quality. Referring to statistical analysis, it was confirmed that physical and mechanical properties of plywood were significantly affected by wood species, except moisture content.

Keywords: mechanical properties, physical properties, plywood, Riau wood species

\section{PENDAHULUAN}

Hutan memegang peranan penting dalam penyediaan bahan baku kayu dan bukan kayu untuk berbagai industri pengolahan kayu dan bukan kayu. Akan tetapi, terdapat kesenjangan antara kemampuan pasokan kayu, terutama dari hutan alam, dan kebutuhan bahan baku kayu pada industri pengolahan kayu di Indonesia. Pada saat ini, jenis-jenis kayu yang biasa diperdagangkan atau jenis kayu komersial makin sulit ditemukan. Jumlah industri kayu lapis di Indonesia dengan kapasitas di atas $6.000 \mathrm{~m}^{3} /$ tahun adalah 230 unit, venir 183 unit, venir lamina atau laminated veneer lumber (LVL) 20 unit, dan papan partikel yang aktif 2 unit (Ditjen PHPL 2019).

Pada tahun 2017, produksi kayu olahan dari industri primer hasil hutan kayu dengan kapasitas lebih dari

Pusat Penelitian dan Pengembangan Hasil Hutan, Jl. Gunung Batu No. 5, Bogor 16118

*Penulis Korespondensi: Email: susupriadi61@gmail.com
$6.000 \mathrm{~m}^{3}$ mencapai sekitar 7,55 juta $\mathrm{m}^{3}$ (kayu lapis, LVL, venir, dan kayu gergajian), 31 juta $\mathrm{m}^{3}$ untuk serpih kayu, dan 7,06 juta ton pulp (KLHK 2018). Untuk memproduksi kayu olahan tersebut, pemerintah bersama mitra kerjanya telah memproduksi kayu bulat sebanyak 37,6 juta $\mathrm{m}^{3}$ pada tahun 2016 dan 43,2 juta $\mathrm{m}^{3}$ pada tahun 2017 sehingga terjadi peningkatan sebesar 14,89\% (KLHK 2018).

Dalam kondisi seperti ini, pemanfaatan kayu pada industri, termasuk industri kayu lapis, tidak dapat hanya mengandalkan jenis-jenis kayu komersial. Industri perlu memperluas pemanfaatan jenis-jenis kayu nonkomersial. Akan tetapi, sebelum dimanfaatkan, sifatsifat setiap jenis kayu nonkomersial tersebut perlu diteliti agar terjadi kesesuaian sifat dengan tujuan penggunaan kayu serta kemampuan kayu tersebut dalam melengkapi dan mensubstitusi jenis kayu komersial. Hasil penelitian tersebut diharapkan dapat memberikan gambaran tentang kemampuan suatu jenis kayu non komersial untuk dibuat kayu olahan, seperti kayu lapis. 
Kayu lapis adalah papan buatan yang terdiri atas lapisan venir yang jumlahnya ganjil, disusun dengan arah serat saling bersilangan tegak lurus, direkat pada tekanan tinggi dengan perekat, dan memiliki kekuatan yang sama atau lebih tinggi dibandingkan dengan kayu aslinya (Kliwon \& Iskandar 2008). Penggunaan kayu menjadi kayu lapis memberikan berbagai keuntungan. Kollman (1975) mengemukakan bahwa keuntungan kayu lapis antara lain: dimensi lebih besar, stabilitas dimensi lebih baik dibandingkan dengan papan biasa, lebih tahan terhadap kelembapan dibandingkan dengan kayu aslinya, sifat isotropisnya lebih homogen dibanding kayu aslinya, dapat diproduksi dengan berbagai macam ketebalan dan berbagai keuntungan lainnya.

Tulisan ini menyajikan hasil penelitian sifat kayu lapis dari lima jenis kayu asal Provinsi Riau yang meliputi kayu punak (Tetramerista glabra Miq.), meranti bunga (Shorea teysmanniana Dyer ex Brandis), mempisang (Alphonsea spp.), suntai (Palaquium burckii H.J.L.), dan pasak linggo (Aglaia argentea Blume). Tujuan penelitian adalah untuk memperoleh gambaran tentang kesesuaian kelima jenis kayu tersebut untuk dibuat kayu lapis. Sasarannya adalah ketersediaan data dan informasi sifat fisik dan mekanik kayu lapis yang dibuat dari lima jenis kayu asal Riau.

\section{METODE PENELITIAN}

\section{Bahan dan Alat}

Venir yang digunakan dalam penelitian ini adalah venir kupas dari kayu punak, meranti bunga, mempisang, suntai, dan pasak linggo. Kelima jenis kayu ini berasal dari Provinsi Riau. Perekat yang digunakan adalah urea formaldehida (UF) cair, hardener (HU-SSP), dan ekstender (tepung terigu). Penampakan perekat UF adalah putih bening, kekentalan 1,2 poise, $\mathrm{pH} 10$, dan kadar padat $50 \%$.

Peralatan yang digunakan meliputi mesin kupas, pemotong venir, meteran dari logam, oven, gelas ukur, pengaduk, viscosimeter, timbangan, kuas, termometer, gergaji mesin meja, mesin kempa dingin, mesin kempa panas, kaliper, dan mesin uji universal (universal testing machine).

\section{Metode Penelitian}

\section{- Pembuatan venir}

Dolok kayu punak, meranti bunga, mempisang, suntai, dan pasak linggo dikupas menjadi venir dengan ketebalan $1,5 \mathrm{~mm}$. Venir dipotong-potong dengan ukuran $40 \mathrm{~cm} \times 40 \mathrm{~cm}$. Venir tersebut kemudian dimasukkan ke dalam oven sampai mencapai kadar air $8-12 \%$.

\section{- Pembuatan campuran perekat}

Campuran perekat dibuat dengan komposisi perekat UF cair (100 g), extender berupa tepung terigu (15 g), hardener $\mathrm{HU}-\mathrm{SSP} /$ pengeras $(0,5 \mathrm{~g})$ dengan tahapan sebagai berikut. a) Bahan ekstender berupa tepung terigu sebanyak $15 \mathrm{~g}$ ditambahkan ke dalam gelas ukur yang berisi $100 \mathrm{~g}$ perekat UF cair dan diaduk perlahan sampai merata. Kekentalan perekat diukur dengan viscosimeter. b) Sebanyak $0,5 \mathrm{~g}$ pengeras (HU-SSP) ditambahkan pada campuran tersebut dan diaduk secara merata.

\section{- Pembuatan kayu lapis}

Pembuatan kayu lapis dilakukan melalui tahapan sebagai berikut. a) Venir ukuran $40 \mathrm{~cm} \times 40 \mathrm{~cm}$ dikeringkan dalam oven hingga mencapai kadar air $10 \%$. b) Permukaan venir dilaburi dengan campuran perekat dengan bobot labur $170 \mathrm{~g} / \mathrm{m}^{2}$. c) Venir yang telah dilaburi perekat kemudian disusun dengan arah serat saling bersilangan tegak lurus, dengan jumlah lapisan lima (multipleks). d) Multipleks 5 lapis dikempa dingin selama 10 menit, setelah itu dikempa panas pada suhu $110^{\circ} \mathrm{C}$ selama 7 menit dengan tekanan spesifik sebesar $10 \mathrm{~kg} / \mathrm{cm}^{2}$.

\section{- Pengujian sifat kayu lapis}

Pembuatan contoh uji untuk pengujian sifat fisis dan mekanis kayu lapis dilakukan 14 hari setelah kayu lapis selesai dibuat. Pengujian yang dilakukan meliputi kadar air, kerapatan, dan keteguhan rekat yang dilakukan menurut Standar Nasional Indonesia (SNI, 2000). Pengujian keteguhan lentur meliputi modulus elastisitas (MOE) dan modulus patah (MOR) yang dilakukan menurut Standar Jepang (JAS 2008), dan pengujian keteguhan tarik dilakukan menurut Standar Amerika (ASTM 1995).

\section{Analisis Data}

Pengujian sifat fisis dan mekanis pada contoh uji dilakukan di Laboratorium Produk Majemuk, Pusat Penelitian dan Pengembangan Hasil Hutan, Bogor. Data hasil pengujian dianalisis menggunakan Rancangan Acak Lengkap (RAL) untuk mengetahui pengaruh jenis kayu pada kadar air, kerapatan, MOE, MOR, keteguhan tarik, dan keteguhan rekat. Setiap perlakuan dibuat sebanyak lima kali ulangan.

Apabila terjadi pengaruh nyata, analisis dilanjutkan dengan uji beda nyata jujur (BNJ). Pengolahan data dilakukan dengan bantuan software program SPSS (Santoso 2018).

\section{HASIL DAN PEMBAHASAN}

\section{Sifat Fisis Kayu Lapis}

Hasil pengujian sifat fisik kayu lapis berupa kadar air, kerapatan, dan hasil uji beda disajikan pada Tabel 1 , sedangkan hasil analisis keragaman disajikan pada Tabel 2.

\section{Kadar Air}

Pengujian kadar air bertujuan untuk mengetahui jumlah air yang terdapat di dalam kayu lapis yang dinyatakan dalam persen (\%) terhadap bobot kayu lapis dalam keadaan kering mutlak atau kering oven. 
Tabel 1 Nilai rata-rata sifat fisis kayu lapis

\begin{tabular}{lcc}
\hline \multicolumn{1}{c}{ Jenis kayu } & Kadar air \% & Kerapatan $\mathrm{g} / \mathrm{cm}^{2}$ \\
\hline Punak & $10,4^{\mathrm{a}}$ & $0,72^{\mathrm{b}}$ \\
Meranti bunga & $11,95^{\mathrm{a}}$ & $0,62^{\mathrm{c}}$ \\
Mempisang & $10,41^{\mathrm{a}}$ & $0,63^{\mathrm{c}}$ \\
Suntai & $10,95^{\mathrm{a}}$ & $0,65^{\mathrm{c}}$ \\
Pasak linggo & $10,75^{\mathrm{a}}$ & $0,93^{\mathrm{a}}$ \\
\hline
\end{tabular}

Keterangan: a)Nilai rata-rata diikuti huruf yang sama tidak berbeda nyata

Tabel 2 Analisis keragaman pengaruh jenis kayu pada sifat fisis kayu lapis

\begin{tabular}{|c|c|c|c|c|c|}
\hline Sumber keragaman & $\mathrm{Db}$ & Jumlah kuadrat & Kuadrat tengah & F Hitung & P Hitung \\
\hline \multicolumn{6}{|l|}{ Kadar air } \\
\hline Jenis kayu & 4 & 7,084 & 1,771 & 1,50 & 0,239 \\
\hline Galat & 20 & 23,576 & 1,179 & & \\
\hline Jumlah & 24 & 30,660 & & & \\
\hline \multicolumn{6}{|l|}{ Kerapatan } \\
\hline Jenis kayu & 4 & 0,324 & 0,081 & 161,59 & $0,000^{* *}$ \\
\hline Galat & 20 & 0,010 & 0,0005 & & \\
\hline Jumlah & 24 & 0,333 & & & \\
\hline
\end{tabular}

Keterangan: **berbeda nyata.

Nilai kadar air rata-rata kayu lapis dari setiap jenis kayu kemudian dibandingkan dengan persyaratan kadar air kayu lapis menurut standar tertentu sehingga dapat diketahui apakah memenuhi syarat atau tidak.

Kadar air kelima jenis kayu yang diteliti berkisar antara $10,41-11,95 \%$. Kayu lapis yang memiliki ratarata kadar air tertinggi adalah kayu lapis meranti bunga, kemudian berturut-turut diikuti oleh kayu lapis suntai, pasak linggo, mempisang, dan punak. Nilai rata-rata kadar air kayu lapis yang diteliti memenuhi Standar Nasional Indonesia dan Standar Jepang yang mempersyaratkan bahwa nilai kadar air kayu lapis tidak lebih dari 14\% (SNI 2000; JAS 2008).

Nilai kadar air kelima jenis kayu lapis hampir sama dengan kadar air kayu lapis akasia (Acacia mangium Willd), yaitu 9,01-14,29\% dan kayu kelampayan (Anthocephalus spp.), yaitu 9,17-10,58\% (Arsad 2011). Hasil penelitian Alam et al. (2012) menunjukkan bahwa kadar air kayu lapis kayu eucalyptus (Eucalyptus camaldulensis Dehn.) adalah 7,4\%, sedangkan kadar air kayu lapis kayu simul (Bombax ceiba L.) adalah $15,5 \%$. Rentang nilai rata-rata kadar air ini sesuai dengan nilai kadar air kering udara untuk iklim Indonesia, yaitu 12-20\% (Praptoyo 2010).

Analisis keragaman menunjukkan bahwa jenis kayu tidak memberikan pengaruh yang nyata pada kadar air kayu lapis pada selang kepercayaan 95\% (Tabel 2). Sementara itu, Haygreen \& Bowyer (1993) menjelaskan faktor-faktor yang mempengaruhi kadar air meliputi jenis kayu, tempat tumbuh, dan umur pohon. Berkaitan dengan kadar air kayu lapis, Arsad (2011) menyatakan bahwa proses pengeringan yang kurang sempurna juga berpengaruh pada kadar air. Semakin tinggi bobot labur yang digunakan maka kadar air kayu lapis cenderung meningkat. Semakin tinggi kerapatan kayu, semakin tinggi pula kadar air kayu lapis.

\section{Kerapatan}

Kerapatan kayu adalah jumlah bahan dinding sel kayu maupun zat-zat lain yang berfungsi memberikan sifat kekuatan kayu (Haygreen \& Bowyer 1993) sehingga nilai kerapatan kayu lapis berpengaruh pada kekuatan kayu lapis yang dihasilkan. Pengujian kerapatan kayu lapis bertujuan untuk mengetahui besar kerapatan pada semua contoh uji yang diteliti sehingga dapat diketahui apakah kayu lapis tersebut termasuk berkerapatan rendah, berkerapatan sedang, atau berkerapatan tinggi.

Kerapatan kelima jenis kayu yang diteliti berkisar antara 0,62-0,93 $\mathrm{g} / \mathrm{cm}^{2}$. Kayu lapis yang memiliki kerapatan tertinggi adalah kayu lapis pasak linggo, kemudian berturut-turut diikuti oleh kayu lapis punak, suntai, mempisang, dan meranti bunga. Standar Nasional Indonesia tidak mensyaratkan besar kerapatan untuk kayu lapis (SNI 2000).

Nilai kerapatan kayu lapis kelima jenis kayu tersebut lebih tinggi dibandingkan dengan kerapatan kayunya. Kerapatan kayu lapis kelima jenis kayu berkisar antara $0,62-0,93 \mathrm{~g} / \mathrm{cm}^{3}$, sedangkan kerapatan kayu dari kelima jenis kayu berkisar antara $0,55-0,88$ $\mathrm{g} / \mathrm{cm}^{3}$. Kecenderungan naiknya kerapatan setelah menjadi kayu lapis juga ditunjukkan oleh hasil penelitian terdahulu, yaitu kerapatan kayu lapis tusam lebih tinggi $\left(0,60-0,76 \mathrm{~g} / \mathrm{cm}^{3}\right)$ dibandingkan dengan kerapatan kayunya $\left(0,55 \mathrm{~g} / \mathrm{cm}^{3}\right)$ (Santoso et al. 1998). Demikian juga hasil penelitian serupa ditemukan pada penelitian pengaruh jenis kayu dan jumlah lapisan pada venir lamina (Iskandar \& Supriadi 2017) yang menyatakan bahwa nilai kerapatan venir lamina kayu pinus $\left(0,62 \mathrm{~g} / \mathrm{cm}^{3}\right)$ dan venir lamina kayu sengon $(0,45$ $\mathrm{g} / \mathrm{cm}^{3}$ ) lebih tinggi dibandingkan dengan kerapatan kayu pinus $\left(0,57 \mathrm{~g} / \mathrm{cm}^{3}\right)$ dan kayu sengon $\left(0,34 \mathrm{~g} / \mathrm{cm}^{3}\right)$. Hal ini disebabkan oleh adanya lapisan perekat dan terjadinya pemadatan pada saat pengempaan venir pada saat pembuatan kayu lapis dan venir lamina. Kelly (1977) menyatakan bahwa kerapatan akhir panel dipengaruhi oleh beberapa faktor, seperti jenis kayu (kerapatan kayu), besar tekanan kempa, jumlah lapisan penyusun panel, kadar perekat, serta bahan tambahan lainnya. 
Analisis keragaman menunjukkan bahwa jenis kayu memberikan pengaruh yang nyata pada kerapatan kayu lapis pada selang kepercayaan 95\% (Tabel 2). Hasil uji beda lanjutan menunjukkan terdapat perbedaan nyata pada kerapatan kayu lapis pasak linggo dibandingkan dengan keempat jenis kayu lainnya, sedangkan kerapatan kayu lapis meranti bunga, mempisang, dan suntai tidak berbeda nyata (Tabel 1).

\section{Sifat Mekanis Kayu Lapis}

Sifat mekanis kayu lapis adalah kemampuan kayu lapis untuk menahan beban dari luar. Sifat mekanis kayu lapis penting untuk diketahui, terutama pada penggunaan kayu lapis yang bersifat khusus, seperti kayu lapis struktural.

Hasil pengujian sifat mekanis kayu lapis berupa modulus elastisitas (Modulus of Elasticity/MOE), modulus patah (Modulus of Rupture/ MOR), keteguhan tarik, dan keteguhan rekat serta hasil uji beda disajikan pada Tabel 3, sedangkan hasil analisis keragaman disajikan pada Tabel 4.

\section{Modulus Elastisitas (MOE)}

Modulus elastisitas merupakan nilai perbandingan antara tegangan dan regangan sepanjang garis elastis sehingga bahan akan kembali ke bentuk semula apabila beban dilepaskan (Mardikanto et al. 2009). Tegangan adalah gaya yang tersebar per satuan luas, sedangkan regangan adalah perubahan ukuran panjang per satuan panjang akibat adanya tegangan (Rachman et al. 1997).
Pada Tabel 3 terlihat bahwa nilai MOE kelima jenis kayu lapis yang diteliti berkisar antara $63.731 \mathrm{~kg} / \mathrm{cm}^{2}$ sampai $123.548 \mathrm{~kg} / \mathrm{cm}^{2}$. Kayu lapis yang memiliki ratarata MOE tertinggi adalah kayu lapis pasak linggo, kemudian berturut-turut diikuti oleh kayu lapis punak, mempisang, meranti bunga, dan suntai. Pada Standar Nasional Indonesia untuk kayu lapis, penggunaan umum (SNI 2000) tidak mensyaratkan besaran MOE.

Hasil penelitian Bal \& Bektay (2014) menunjukkan bahwa MOE kayu lapis yang dibuat dari venir Eucalyptus grandis, Fagus orientalis, dan Poplar (Populus $\mathrm{x}$ ueramericana) dan direkat dengan perekat urea formaldehida secara berturut-turut adalah sebesar $9346 \mathrm{MPa}$ atau $95.329 \mathrm{~kg} / \mathrm{cm}^{2}, 8636 \mathrm{MPa}$ atau $88.087 \mathrm{~kg} / \mathrm{cm}^{2}$, dan $6875 \mathrm{Mpa}$ atau $70.125 \mathrm{~kg} / \mathrm{cm}^{2}$. Sementara itu, Alam et al. (2012) melaporkan bahwa MOE kayu lapis dari Eucalyptus camaldulensis Dehn. dan Bombax ceiba L. yang dibuat dengan menggunakan perekat urea formaldehida secara berturutturut adalah sebesar $7879 \mathrm{~N} / \mathrm{mm}^{2}$ atau $80.366 \mathrm{~kg} / \mathrm{cm}^{2}$ dan $3870 \mathrm{~N} / \mathrm{mm}^{2}$ atau $39.474 \mathrm{~kg} / \mathrm{cm}^{2}$. Sulastiningsih dan Krisdianto (2012) melaporkan bahwa MOE kayu lapis sengon dan kayu lapis campuran sengon dan anyaman bambu secara berturut-turut adalah sebesar 22.860 dan $36.960 \mathrm{~kg} / \mathrm{cm}^{2}$.

Analisis keragaman menunjukkan bahwa jenis kayu berpengaruh nyata pada MOE kayu lapis pada selang kepercayaan $95 \%$ (Tabel 4). Hasil uji beda lanjutan menunjukkan terdapat perbedaan nyata MOE kayu lapis pasak linggo dibandingkan dengan keempat jenis kayu lainnya, sedangkan MOE kayu lapis meranti

Tabel 3 Nilai rata-rata sifat mekanis kayu lapis

\begin{tabular}{|c|c|c|c|c|}
\hline Jenis kayu & MOE $\mathrm{kg} / \mathrm{cm}^{2}$ & MOR kg/cm² & $\mathrm{KT} \mathrm{kg} / \mathrm{cm}^{2}$ & $\mathrm{KR} \mathrm{kg} / \mathrm{cm}^{2}$ \\
\hline Punak & $92.015^{b}$ & $633,0^{b}$ & $461,6^{b}$ & $31,79^{a}$ \\
\hline Meranti bunga & $76.117^{c}$ & $631,8^{b}$ & $466,9 \mathrm{~b}$ & 20,73 b \\
\hline Mempisang & $78.447^{c}$ & $658,1 \mathrm{ab}$ & 494,5 b & $22,15 \mathrm{~b}$ \\
\hline Suntai & $63.731^{d}$ & $517,0^{b}$ & $500,0^{b}$ & $18,97^{b}$ \\
\hline Pasak linggo & $123.548^{a}$ & $1.052,0 \mathrm{a}$ & $1.095,0$ a & $22,33 b$ \\
\hline
\end{tabular}

Keterangan: $\mathrm{MOE}=$ Modulus elastisitas; MOR = Modulus patah; KT = Keteguhan tarik; KR = Keteguhan rekat; a)Nilai ratarata yang diikuti huruf yang sama tidak berbeda nyata.

Tabel 4 Analisis keragaman pengaruh jenis kayu pada sifat mekanis kayu lapis

\begin{tabular}{|c|c|c|c|c|c|}
\hline Sumber keragaman & $\mathrm{Db}$ & Jumlah kuadrat & Kuadrat tengah & F Hitung & P Hitung \\
\hline \multicolumn{6}{|l|}{ MOE } \\
\hline Jenis kayu & 4 & 10.468.316.601 & 2.617.079.150 & 62,28 & $0,000^{* *}$ \\
\hline Galat & 20 & 840.382 .844 & 42.019.142 & & \\
\hline Jumlah & 24 & 11.308.699.445 & & & \\
\hline \multicolumn{6}{|l|}{ MOR } \\
\hline Jenis kayu & 4 & 842.700 & 210.675 & 4,75 & $0,007^{* *}$ \\
\hline Galat & 20 & 887.847 & 44.392 & & \\
\hline Jumlah & 24 & 1.730 .547 & & & \\
\hline \multicolumn{6}{|l|}{ Keteguhan tarik } \\
\hline Jenis kayu & 4 & 1.516 .704 & 379.176 & 11,83 & $0,000^{* *}$ \\
\hline Galat & 20 & 640.971 & 32.049 & & \\
\hline Jumlah & 24 & 2.157 .675 & & & \\
\hline \multicolumn{6}{|l|}{ Keteguhan rekat } \\
\hline Jenis kayu & 4 & 498,5 & 124,62 & 6,14 & $0,002^{* *}$ \\
\hline Galat & 20 & 405,8 & 20,29 & & \\
\hline Jumlah & 24 & 904,3 & & & \\
\hline
\end{tabular}

Keterangan: **berbeda nyata. 
bunga dan mempisang tidak berbeda nyata (Tabel 3). Hasil analisis keragaman ini mendukung informasi di atas yang menunjukkan bahwa MOE kayu lapis pasak linggo lebih tinggi dibanding MOE kayu lapis punak, meranti bungo, mempisang, dan suntai. Di samping itu, kayu lapis pasak linggo juga memiliki MOE yang lebih tinggi dibanding kayu lapis Fagus orientalis, Populus $\mathrm{x}$ ueramericana, Eucalyptus camaldulensis Dehn., Bombax ceiba L., sengon, serta campuran sengon dan anyaman bambu. Hal ini terjadi karena nilai kerapatan kayu lapis pasak linggo jauh lebih tinggi dibanding kerapatan kayu lapis dari jenis kayu tersebut.

MOE kelima jenis kayu lapis berada di bawah rata-rata MOE venir lamina yang terbuat dari kayu sengon $\left(126.867 \mathrm{~kg} / \mathrm{cm}^{2}\right)$ dan kayu pinus (121.657 $\mathrm{kg} / \mathrm{cm}^{2}$ ) maupun campuran kedua jenis kayu tersebut, yaitu $123.800 \mathrm{~kg} / \mathrm{cm}^{2}$ dengan jumlah lapisan yang terdiri atas 4, 6, dan 8 lapis, dengan menggunakan perekat urea formaldehida (Iskandar \& Supriadi 2017), sedangkan pada penelitian ini terdiri atas 5 lapis. Jenis perekat yang digunakan dalam penelitian ini sama dengan yang digunakan dalam penelitian venir lamina kayu sengon dan pinus. Nilai MOE kayu lapis yang lebih rendah pada penelitian ini diduga karena arah lapisan pada kayu lapis adalah bersilangan tegak lurus, sedangkan pada venir lamina semua lapisannya disusun dengan arah sejajar serat.

\section{Modulus Patah (MOR)}

MOR merupakan besaran yang menunjukkan ketahanan komponen dalam menahan defleksi yang disebabkan oleh gaya geser (Mardikanto et al. 2009). Nilai MOR kelima jenis kayu lapis yang diteliti berkisar antara $517 \mathrm{~kg} / \mathrm{cm}^{2}$ sampai $1.052 \mathrm{~kg} / \mathrm{cm}^{2}$. Kayu lapis yang memiliki rata-rata MOR tertinggi adalah kayu lapis pasak linggo, kemudian berturut-turut diikuti oleh kayu lapis mempisang, punak, meranti bunga, dan suntai. SNI (2000) tidak mensyaratkan besar MOR untuk kayu lapis untuk penggunaan umum.

Fitri et al. (2018) melaporkan bahwa kayu lapis batai (Paraserianthes falcataria) dan kelampayan (Neolamarckia cadamba) yang direkat dengan melamin formaldehida memiliki nilai MOR secara berturut-turut sebesar 20,38 MPa atau $207,9 \mathrm{~kg} / \mathrm{cm}^{2}$ dan $40,04 \mathrm{MPa}$ atau $408,4 \mathrm{~kg} / \mathrm{cm}^{2}$, sedangkan kayu lapis yang dibuat dari Eucalyptus camaldulensis Dehn. dan Bombax ceiba L. yang direkat dengan urea formaldehida memiliki nilai MOR secara berturut-turut sebesar $68,6 \mathrm{MPa}$ atau $699,7 \mathrm{~kg} / \mathrm{cm}^{2}$ dan $26,91 \mathrm{MPa}$ atau $274,5 \mathrm{~kg} / \mathrm{cm}^{2}$ (Alam et al. 2012).

MOR kayu lapis dari kelima jenis kayu asal Riau berada di atas rata-rata MOR venir lamina yang terbuat dari kayu sengon, yaitu $381,92 \mathrm{~kg} / \mathrm{cm}^{2}$ dan kayu pinus, yaitu $511,76 \mathrm{~kg} / \mathrm{cm}^{2}$ (Iskandar \& Supriadi 2017). MOR kayu lapis yang tinggi ini diduga karena kayu lapis ini memiliki kerapatan yang lebih tinggi $\left(0,65 \mathrm{~g} / \mathrm{cm}^{3}\right)$ dibanding kerapatan venir lamina kayu sengon $(0,42$ $\left.\mathrm{g} / \mathrm{cm}^{2}\right)$ dan kayu pinus $\left(0,62 \mathrm{~g} / \mathrm{cm}^{2}\right)$. Hasil penelitian lainnya (Iskandar 2014) menyatakan bahwa MOR venir lamina yang dibuat dari kayu sengon berkisar antara $476,03-721,81 \mathrm{~kg} / \mathrm{cm}^{2}$. MOR kayu lapis pasak linggo lebih tinggi dibandingkan dengan MOR bambu lamina yang lapisan tengahnya menggunakan kayu tusam, yaitu $962 \mathrm{~kg} / \mathrm{cm}^{2}$ (Sulastiningsih et al. 2005). Hal ini diduga karena kerapatan kayu lapis pasak linggo lebih tinggi $\left(0,93 \mathrm{~g} / \mathrm{cm}^{3}\right)$ dibandingkan dengan kerapatan bambu lamina yang lapisan tengahnya menggunakan kayu tusam $\left(0,64 \mathrm{~g} / \mathrm{cm}^{3}\right)$.

Hasil analisis keragaman menunjukkan bahwa jenis kayu berpengaruh nyata pada MOR kayu lapis pada selang kepercayaan 95\% (Tabel 4). Hasil uji beda lanjutan menunjukkan terdapat perbedaan nyata MOR kayu lapis pasak linggo dengan keempat jenis kayu lainnya (Tabel 3).

\section{Keteguhan Tarik}

Pengujian keteguhan tarik bertujuan untuk mengetahui besar nilai keteguhan tarik pada semua contoh uji kayu lapis yang diteliti. Nilai keteguhan tarik kelima jenis kayu lapis yang diteliti berkisar antara 550 $\mathrm{kg} / \mathrm{cm}^{2}$ sampai $1.095 \mathrm{~kg} / \mathrm{cm}^{2}$. Kayu lapis yang memiliki rata-rata keteguhan tarik tertinggi adalah kayu lapis pasak linggo, kemudian secara berturut-turut diikuti oleh kayu lapis suntai, mempisang, punak, meranti bunga, dan punak. SNI (2000) tidak mensyaratkan besaran keteguhan tarik untuk kayu lapis yang ditujukan untuk penggunaan umum atau yang tidak menahan beban (non structura).

Hasil penelitian Iskandar et al. (1990) menunjukkan bahwa kayu lapis yang dibuat dari venir kayu palapi (Tarrietia javanica BL.) dan direkat dengan urea formaldehida memiliki keteguhan tarik sebesar 311,2 $\mathrm{kg} / \mathrm{cm}^{2}$, sedangkan yang dibuat dari venir kayu meranti (Shorea koordersii Brandis.) memiliki keteguhan tarik sebesar $361,08 \mathrm{~kg} / \mathrm{cm}^{2}$. Hasil penelitian terdahulu lainnya menunjukkan bahwa kayu lapis yang dibuat dari venir kayu sengon dan direkat dengan perekat urea formaldehida memiliki nilai keteguhan tarik sebesar $375,9 \mathrm{~kg} / \mathrm{cm}^{2}$, sedangkan kayu lapis sengon dengan lapisan inti anyaman bambu tali memiliki nilai keteguhan tarik sebesar $647 \mathrm{~kg} / \mathrm{cm}^{2}$ (Sulastiningsih \& Krisdianto 2012).

Hasil analisis keragaman menunjukkan bahwa jenis kayu berpengaruh nyata pada keteguhan kayu lapis pada selang kepercayaan 95\% (Tabel 4). Seperti pada MOR, hasil uji beda lanjutan menunjukkan terdapat perbedaan nyata keteguhan tarik kayu lapis pasak linggo dibandingkan dengan keempat jenis kayu lainnya (Tabel 3). Berdasarkan uraian di atas dapat diketahui bahwa terdapat korelasi antara keteguhan tarik kayu lapis dengan kerapatan kayu lapis. Hal ini sejalan dengan hasil penelitian Sulastiningsih \& Sutigno (1992) yang menyatakan bahwa terdapat hubungan yang erat antara kerapatan kayu lapis 
dengan beberapa sifat mekanis kayu lapis. Semakin tinggi kerapatan kayu lapis semakin tinggi pula sifat mekanisnya.

\section{Keteguhan Rekat}

Pembuatan kayu lapis memerlukan perekat organik untuk merekatkan lembaran venir sehingga menjadi kayu lapis. Pada proses perekatan terjadi perekatan mekanik dan perekatan spesifik. Perekatan mekanik terjadi karena adanya sebagian perekat masuk ke dalam pori-pori kayu yang kemudian kering dan mengeras, sementara perekatan spesifik terjadi dengan melibatkan ikatan-ikatan kimia, ikatan hydrogen, dan ikatan Van der Walss (Ruhendi et al. 2007). Santoso et al. (2016) menyatakan bahwa semakin banyak partikel perekat yang bereaksi dengan kayu pada proses perekatan, akan semakin meningkatkan kete-guhan rekatnya. Pengujian keteguhan rekat bertujuan untuk mengetahui kualitas hasil perekatan pada semua contoh uji kayu lapis yang diteliti. Nilai keteguhan rekat rata-rata kayu lapis dari setiap jenis kayu kemudian dibandingkan dengan standar tertentu sehingga dapat diketahui apakah memenuhi syarat atau tidaknya nilai keteguhan rekat tersebut.

Nilai keteguhan rekat kelima jenis kayu lapis yang diteliti berkisar antara $18,97-31,79 \mathrm{~kg} / \mathrm{cm}^{2}$. Kayu lapis yang memiliki rata-rata keteguhan rekat tertinggi adalah kayu lapis punak, kemudian secara berturutturut diikuti oleh kayu lapis pasak lingo, mempisang, meranti bunga, dan suntai. Keteguhan rekat kelima jenis kayu lapis yang diteliti memenuhi Standar Nasional Indonesia yang mempersyaratkan bahwa nilai keteguhan rekat kayu lapis minimum $7 \mathrm{~kg} / \mathrm{cm}^{2}$ (SNI 2000).

Nilai keteguhan rekat kelima jenis kayu lapis berada di atas rata-rata keteguhan rekat kayu lapis tusam yang menggunakan perekat fenol formaldehida masingmasing dengan campuran ekstender terigu, yaitu berkisar antara $10,40-14,14 \mathrm{~kg} / \mathrm{cm}^{2}$ dan kayu lapis tusam yang menggunakan perekat yang sama dengan ekstender gaplek, yaitu berkisar antara 9,39-13,04 $\mathrm{kg} / \mathrm{cm}^{2}$ (Santoso et al. 1998). Hal ini diduga karena pengaruh jenis kayu dan kualitas bahan perekat yang digunakan.

Hasil analisis keragaman menunjukkan bahwa jenis kayu berpengaruh nyata pada keteguhan rekat kayu lapis pada selang kepercayaan $95 \%$ (Tabel 4). Hasil uji beda lanjutan menunjukkan terdapat perbedaan nyata antara keteguhan rekat kayu lapis punak dibandingkan dengan keempat jenis kayu lainnya (Tabel 3). Selain faktor jenis kayu, keteguhan rekat dipengaruhi juga oleh kualitas bahan perekat (dan campuran ekstendernya), proses pelaburan, bobot labur (Arsad 2011), dan zat ekstraktif kayu (Iskandar 1990). Semakin tinggi kadar ekstender, umumnya kadar air dan keteguhan rekat semakin menurun (Hadi 1996). Penambahan ekstender yang lebih banyak dari $20 \%$ dapat mengurangi keteguhan rekat kayu lapis, tapi keteguhan rekat yang dihasilkan masih tergolong baik (Perry 1994).

\section{KESIMPULAN}

Sifat fisik dan mekanik kayu lapis dari lima jenis kayu asal Riau menunjukkan kadar air berkisar antara 10,4-10,95\%, kerapatan 0,65-0,93 g/ $\mathrm{cm}^{3}$, MOE $63.371-123.548 \mathrm{~kg} / \mathrm{cm}^{2}$, MOR $517-1.052 \mathrm{~kg} / \mathrm{cm}^{2}$, keteguhan tarik $461,6-1.095 \mathrm{~kg} / \mathrm{cm}^{2}$, dan keteguhan rekat 18,97-31,79 kg/cm². Kadar air dan keteguhan rekat kayu lapis yang dibuat semuanya memenuhi Standar Nasional Indonesia untuk Kayu lapis penggunaan umum. Kayu lapis pasak linggo memiliki kualitas terbaik dibanding keempat jenis kayu lainnya. Secara statistik, jenis kayu berpengaruh nyata pada kerapatan, MOE, MOR, keteguhan tarik, dan keteguhan rekat, sedangkan pada kadar air, jenis kayu tidak berpengaruh nyata.

\section{DAFTAR PUSTAKA}

[ASTM] American Society for Testing and Materials. 1995. Standard Test Methods for Structural Panels in Tension. Annual Book of ASTM Standard. ASTM D 3500-90. Philadelphia.

Arsad E. 2011. Sifat fisik kayu lapis berbahan baku kayu akasia (Acacia mangium Willd.) dan kelampayan (Anthocephalus spp.). Jurnal Riset Industri Hasil Hutan. (3)2: 1-6. https:// doi.org/10.24111/jihh.v3i2.1188

Bal BC, Bektay I. 2014. Some Mechanical Properties of Plywood Produced from Eucalyptus, Beech, and Poplar Veneer. Maderas. Ciencia y tecnologia 16(1): 99-108. https://doi.org/10.4067/S0718-221 X2014005000009

Direktorat Jenderal Pengelolaan Hutan Produksi Lestari (PHPL). 2019. Jumlah dan kapasitas ijin produksi industri primer hasil hutan kayu (IPHHK) di atas $6.000 \mathrm{~m}^{3} /$ tahun per Provinsi sampai dengan Mei 2019. Ditjen PHPL Kementerian Lingkungan Hidup dan Kehutanan Jakarta.

Hadi F. 1996. Pengaruh kadar ekstender dan variasi waktu tekan terhadap keteguhan dan daya tahan rekat kayu lapis jenis meranti merah (Shorea spp.) dan kapur (Dryobalanops sp.). [Skripsi]. Samarinda (ID): Universitas Mulawarman.

Haygreen JG, Bowyer JL. 1993. Forest Product and Wood Science, an Introduction. lowa (US): lowa State University Press.

Iskandar MI, Kliwon S, Sutigno P. 1990. Sifat Venir dan Kayu Lapis 8 Jenis Kayu dari Sulawesi Tengah. Jurnal Penelitian Hasil Hutan 8(4): 150-156.

Iskandar. 1990. Keteguhan rekat kayu meranti merah (Shorea spp.) dengan menggunakan perekat styrofoam. [Skripsi]. Bogor (ID): Institut Pertanian Bogor. 
Iskandar MI, Supriadi A. 2017. Pengaruh jenis kayu dan jumlah lapisan terhadap sifat venir lamina. Jurnal IImu Pertanian Indonesia. 22(1): 34-40. https://doi.org/10.18343/jipi.22.1.34

[JAS] Japanese Agricultural Standard. 2008. Japanese Agricultural Standard for Plywood. Ministry of Agriculture, Forestry and Fisheries.

Kelly MW. 1977. Critical literature review of relationship between processing parameters and physical properties of particleboards. General Technical Report FLL-10.

[KLHK] Kementerian Lingkungan Hidup dan Kehutanan. 2018. Statistik Kementerian Lingkungan Hidup dan Kehutanan 2017. Jakarta (ID).

Kliwon S, Iskandar MI. 2008. Teknologi Kayu Lapis dan Produk Sekundernya. Pusat Penelitian dan Pengembangan Hasil Hutan. Bogor (ID): Badan Penelitian dan Pengembangan Kehutanan.

Mardikanto T.R., Karlinasari L \& Bahtiar ET. 2009. Sifat Mekanis Kayu. Fakultas Kehutanan IPB, Bogor.

Muhammad-Fitri S, Suffian M, Wan-Mohd-Nazri WAR \& Nor-Yuziah Y. 2018. Mechanical Properties of Plywood from Batai (Paraserianthes falcataria), Eucalyptus (Eucalyptus pellita) and Kelempayan (Neolamarckia cadamba) with Different Layer and Species Arrangement. Journal of Tropical Forest Science 30(1): 58-66. https://doi.org/ 10.26525/jtfs2018.30.1.5866

Alam DMN, Islam MN, Rahman KS \& Alam MR. 2012. Comparative Study on Physical and Mechanical Properties of Plywood Produced from Eucalyptus (Eucalyptus camaldulensis Dehn.) and Simul (Bombax ceiba L.) Veneers. Research Journal of Recent Sciences 1(9): 54-58.

Perry TD. 1994. Modern Wood Adhesives. London (EN): Pitman and Sons.

Praptoyo H. 2010. Sifat anatomi dan sifat fisika kayu mindi (Melia azedarach Linn) dari hutan rakyat di Yogyakarta. Jurnal IImu Kehutanan. (4)1: 21-27.
Rachman O, Hardjo, S, Suwirman, M. 1997. Perbaikan Teknik pelengkungan rotan melalui perendaman dengan larutan dimetil sulfoksida. Buletin Penelitian Hasil Hutan. 15(4): 299-311.

Ruhendi S, Koroh DN, Syamani FA, Yanti H, Nurhaida, Saad, S, Sucipto T. 2007. Analisis Perekatan Kayu. Bogor ID): Institut Pertanian Bogor.

Santoso A, Firmanti A, Karno RA. 1998. Pengaruh penambahan ekstender dalam perekat fenol formaldehida terhadap keteguhan rekat kayu lapis tusam. Buletin Penelitian Hasil Hutan. 15(5): 337-347.

Santoso A, Sulastiningsih IM, Pari G, Jasni. 2016. Pemanfaatan ekstrak kayu merbau untuk perekat produk laminasi bambu. Jurnal Penelitian Hasil Hutan. 34(2): 89-100. https://doi.org/10.20 886/jphh.2016.34.2.89-100

Santoso S. 2018. SPPS Versi 25. Jakarta (ID): PT. Elex Media Komputindo.

[SNI] Standar Nasional Indonesia. 2000. Kayu lapis penggunaan umum (SNI 01-5008.2-2000). Jakarta.(ID): Badan Standarisasi Nasional.

Sulastiningsi IM, Sutigno P. 1992. Pengaruh Campuran Jenis Kayu terhadap Beberapa Sifat Kayu Lapis. Jurnal Penelitian Hasil Hutan 10(3): 90-96. https://doi.org/10.20886/jphh.2005.23. 1.1522

Sulastiningsih IM, Hadjib N, Santoso A. 2005 Pengaruh lapisan kayu terhadap sifat bambu lamina. Jurnal Penelitian Hasil Hutan. 23(1): 15-22.

Sulastiningsih IM, Krisdianto. 2012. Physical and mechanical properties of combination plywood sengon and bamboo. Proceedings of International Seminar Strategies and Challenges on Bamboo and Potential Non Timber Forest Products (NTFPs) Management and Utilization. Center for Forest Productivity Improvement Research and Development. Bogor (ID): 131-135. 